\title{
SAVITRIBAI PHULE THE FIRST LADY TEACHER AND SOCIAL REFORMER IN NINETEENTH CENTURY OF INDIA
}

\author{
Sourav Chandra Garaian ${ }^{1}$, Dr. Subir Sen ${ }^{2 *}$ \\ ${ }^{I}$ Research Scholar, Sidho-Kanho-Birsha University, Purulia, West Bengal, 723104, India \\ ${ }^{2}$ Associate Professor, Sidho-Kanho-Birsha University, Purulia, West Bengal, 723104, India
}

Article DOI: https://doi.org/10.36713/epra7439

DOI No: 10.36713/epra7439

\begin{abstract}
Savitribai Phule was an important social reformer and leading character of the then Maharashtra. She was the first lady teacher of first girl's school in India. Not only a teacher she was a great social reformer. In nineteenth century she was a power source of woman education and woman empowerment. She was also a founder of modern Marathi poetry. At this crisis time she and Jyotirao Phule established a girl's school with nine students in 1848 at Pune in Bhide Wada and she also taught in this school. She did not stop there, she raised her voice against the practice of child marrage, sati pratha and child widows for the betterment of the human race and society. At the same time, she promoted a positive attitude towards widow remarriage. She was an idol of Dalit and Mang community like Bhimrao Ramji Ambedkar. She also moved against untouchability and rule out the discrimination grounded on caste and gender.
\end{abstract}

\section{INTRODUCTION}

Savitribai Phule was born on $3^{\text {rd }}$ January, 1831 in Naigaon village, Satara district in Maharashtra. Her parents were Lakshmi Bai and Khandoji Nevse Patil. She got married with Jyotirao Phule(Mahatma Jotiba Phule) in the age of 9 in 1840. Jyotirao Phule was also a great thinker, writer, social activist and anti-caste social reformer. Savitribai Phule and Jotirao Phule had no own children. They adopted a Brahmins widow child. The name of that child was Yashawant Rao. Savitribai Phule started schooling after her marriage. Because of her interest in studying, Jyotirao Phule insisted her to start educating herself. After clearing the exam of third and fourth year from a normal school she became interested about teaching. After that she took training to nurture her skills at Ms Farar's Institution in Ahmednagar. Jyotirao Phule was always standing and greatly supports all activities of Savitribai Phule. She with her husband makes many social services.
Savitribai Phule and Jyotirao Phule made many school for women education and low cast child. For this activity in 16 November 1852 honored the Phule family for their contributions in the ground of education by the British government. The Pune City Corporation built a memorial in 1983 to pay homage to her. Government of India released a postal stamp in her honor on March 10, 1998. In 2015 The University of Pune changed the name of the university and it was renamed as Savitribai Phule Pune University. Google create Google doodle to celebrate her 186th birth anniversary on January 3, 2017.

\section{LITERATURE REVIEW}

Katke, S. M. (2019) Conducted a study entitled "Savitribai Phule Contribution towards Indian Social Elements - A Study"

In this study it was mentioned that Savitribai Jyotirao Phule was a famous Indian social reformer, educator, 
and poet who played an active role in the education and empowerment of women in the 19th century. Savitribai is one of the few educated women of this time and is responsible for having founded the first girls' school in Pune, Bhide Wada, with her husband Jyotirao Phule. She went to great lengths to raise and emancipate child widows, opposed child marriage and Sati Pratha, and advocated the remarriage of widows. As a major protagonist of Maharashtra's social reform movement, she is considered an icon of the Dalit Mang caste along with B. R. Ambedkar and Annabhau Sathe. She campaigned against untouchability and actively campaigned for the abolition of caste and gender discrimination.

Pandey, R. (2019) Conducted a study entitled 'Locating Savitribai Phule's Feminism in the Trajectory of Global Feminist Thought"

Feminism shows shades of the first wave of feminism when she talked about the ability to reason, selfreliance, and public schools. Her feminism showed traces of the second wave of feminism as she raised her voice over shelters and marriages between castes. Her feminism also showed some valuable characteristics of third wave feminism when she talked about raising women with different identities and bringing Stree Shudra Atishudra together. Savitribai was also the first woman to put her husband's stake in the whole history of India. Her decision to light her husband's pyre must have shocked the most radical feminists all the time.

Mangala, K. D. (2018) Conducted a study entitled "Savitribai Phule: Revolutionary work and literature" In this study the important issues are Savitribai's educational thinking is an era promoter. Savitribai Phule can be proudly mentioned as a positive force that shapes the female life of Maharashtra. It is glad to say that Savitribai gave prestige to the woman because of Savitribai, a noble and revolutionary spectator of her personality and activities. This light of innovation is a motivation for women who have worked in various fields and proved their mettle. Savitribai's work was challenging the difficulty of the times, Because Savitribai thought and worked for the freedom of all women and the Shudratishudra society in the world of slavery in the then orthodox society of the nineteenth century. Krantijyoti Savitribai Phule's position as a champion of the downtrodden and a supporter of teaching is inevitable in the wake of India's first teacher women's liberation movement. Phenomenal Education is a instrument for social transformation. He wanted to generate awareness in the society through education. Savitribai Phule was one of the immense educators of India who laid down the basic idea of education for humanity about 175 years before. Savitribai Phule's social and educational work is amazing and phenomenal. At the same time, Savitribai also produced literature. Her literature was enlightening the society. His entire literature was on social awareness. All literature was for the welfare of the citizens.

Jain, S. (2016) Conducted a study entitled "Caste and Education: The Vision of Mahatma Jotirao Phule"

There major findings are the ideologies the ideologies of the anti-caste movements were geared towards the "emancipation" that all intellectuals needed for Dalits. Phule was the first anti-caste intellectual to think about education for the masses (for Dalits). He fought against Brahmanism, which is "superstition, bag of tricks, weapon of domination" (Omvedt, Dalit Visions 8). Phule is not only considered the main figure of the anticaste movement, but also a protester for the empowerment of women His wife, Savitribai Phule, is the main contributor to the education mission for oppressed women. According to Jyotirao Phule, the education of women and the lower caste deserves priority as their social position and condition in society are greatly degraded.

Somkuwar, P. (2014) Conducted a study entitled "Dalit Women Poets and New Themes in Poetry"

Major issues discussed in this work are as follows Dalit literature in the hands of modern women's writers has gone through a multidimensional revolutionize. Adjudging new themes and concepts it hardly remains the literature of lower classes. These modern poets writing is not only the writing of lamentation, breastbeating, praising or even consideration but also feministic, reflective and universal. By representing universal themes in their text, they have taken the movement of Dr Ambedkar on a high peak. Their society as well as Dalit Writers from first and second generations has sky-scraping hopes from these Modern Dalit Women poets. Finally all discussion indicates to the quote Dr Ambedkar who said, "I measure the progress of the community by the degree of progress which women have achieved.

Wolf, T. (2011) Conducted a study on Savitribai Phule. It is opined that for present day, every literate woman of India, anywhere in the world, stands as testimony to the influence of the four original and extraordinary ideas shared by Comenius and Savitribai: that education for every child, without exception, must be universally accessible, child sensitive, intellectually critical, and socially reforming. And every girl child, in any school, on any day, in India sitting at the side of boys, reading a book, exploring the Internet, learning 
new things. It is a Savitribai-kind of India. Might just such a different arrangement incite a future with a different kind of social structure a world venue learning place different from the detention center house kind of culture within which Savitribai lived? If so, then I don't know the children of India may yet sing in a pleasant house, little canaries freed into a most original and extraordinary future a Comenius and Savitribai kind of future.

\section{ROLE IN WOMEN EDUCATION \& EMPOWERMENT}

Savitribai Phule is famous for her massive involvement towards empowerment and emancipation of women through education and for the elimination of slavery and inequity on the grounds of religion, caste and race. To make this thinking a reality Savitribai Phule and Jyotirao Phule established a girl's school with nine students in 1848 at Pune in Bhide Wada. For this step both faced the rejection by the society. At this dangerous situation a friend Usman Sheikh and his sister Fatima Sheikh extended a helping hand. They also handed over their accommodation to start school. Savitribai Phule became first teacher in this school. In this school included western curriculum of social studies, mathematics and science. After that to fight against untouchability Savitribai Phule and Jyotirao Phule start another school for children from the Mang and Mahar castes in 1852. In the year of 1852, in Pune, Savitribai Phule and her husband established three different schools for girls. In these three schools total 150 students were enrolled. Over the year Savitribai Phule starts total 18 school for educating women, children as well as other people from different downtrodden castes. All those social activities became an eyesore for the upper castes of Pune. They opposed educating lower casts or dalits. Savitribai Phule was too much harassed and humiliated by the upper castes peoples. They throw Cow dung, mud and stones on Savitribai Phule.but she remained stand on her goal and she and her husband started an evening school for the different day laborers and farmers.

The revelation of all aspects shows that Savitribai Phule was a feminist or social reformer who established the base of women's education in India when there was full of orthodoxy, strict caste division and superstition about 180 year ago. She also raised her strong voice against child marriage, feticide, cast discrimination etc. This was a very exemplary event in India at that time. Later, great thinkers like Dr. Bhimrao Ramji Ambedkar, Rabindranath Tagore and Swami Vivekananda were also expressed similar thoughts on women education and empowerment.
About two years before the birth of Savitribai Phule, Raja Ram Mohan Roy, with the help of Lord Bentinck, abolished the crucial practice of satidaha pratha in 1829. Then in 1856, under the initiative of Ishwar Chandra Vidyasagar, the Widow Marriage Act got official approval. Ishwar Chandra Vidyasagar also set up a total of 38 women's education centers in West Bengal in 1858, which was a contemporary of Savitribai Phule. That is to say, the auspicious effect of the voice raised by Savitribai in Maharashtra entered West Bengal through the hands of Ishwar Chandra Vidyasagar and later Dr. Bhimrao Ramji Ambedkar, Rabindranath Tagore, Swami Vivekananda spread it all over India and the world, as a result of which today's improved society.

\section{ROLE AS SOCIAL REFORMER}

Savitribai Phule inaugurated the Mahila Seva Mandal to make women awareness about their rights, self-respect and other social issues. She was done many social activities to protest the traditional narrowmindedness about widows. After that Savitribai Phule and Jyotirao Phule started a care centre for pregnant Brahmin widows and pregnant rape victims name Balhatya Pratibandhak Griha.. In this care centre they helped deliver and save their children, For this wonderful movement it possible to prevent infanticide. At this time Savitribai Phule and Jyotirao Phule adopt a child from a Brahmin widow called Kashibai. This adoption sends a great massage to society. Not only that Jyotirao Phule works about widow re-marriage and against the child marriage and sati pratha. After that in 1897 Savitribai Phule and her adopted son, Yashawant Rao starts a clinic at pune to care for those affected by the Pandemic of the bubonic plague in the region around Nalasopara. In this pandemic situation everybody left but Savitribai Phule did not hesitate to fight against the crisis situation. She even gave up her life to fight in this pandemic situation.

\section{ROLE AS AUTHOR AND POET}

Savitribai Phule was a pronounced author and poet. She wrote Kavya Phule (1854) and Bavan Kashi Subodh Ratnakar (1892) and also wrote a poem entitled "Go, Get Education". Through these publications she was try to encourage and motivate women and lower cast's peoples and also tries to encourage and motivate who opposed her works and contribution to the society. Every one of her works was carried out for the welfare of the society and woman education. On the other hand Jyotirao Phule was also a great thinker, writer. he wrote Tritiya Ratna in 1855, Brahmananche Kasab in 1869, 
Gulamgiri in 1873, Sarvajanic Satya Dharmapustak in 1891 etc. He also summarizes Savitribai Phule.

\section{Award and Honor}

In 16 November 1852 honored the Phule family for their contributions in the ground of education by the British government and acknowledged as Savtribai Phule was the best teacher. On the other hand to show respect a monument was formed in her honor by the Pune City Corporation in 1983. After that India Post released a stamp in her honor on 10th March, 1998. In 2015 The University of Pune changed the university name and it was renamed as Savitribai Phule Pune University. On 3rd January, 2017 Google create Google doodle to celebrate her 186th birth anniversary.

\section{Demise}

When Savitribai Phule and her adopted son, Yashawant Rao starts a clinic at pune and Yashawant Rao served valuable service as a doctor for the suffering people in the bubonic plague at this time Savitribai Phule took the effected people to the clinic where her son treated them. She caught the Plague while trying to serving the son of Pandurang Babaji Gaekwad and she died a heroic death to it on the 10th of March, 1897.

\section{CONCLUSION}

Savitribai Phule a name that was closely associated with women education and equal rights. In the $19^{\text {th }}$ century saw the beginning of spread of women education mainly by Savitribai Phule. Not only education, she also helped women and lower cast's peoples to live with their heads held high in the society. She was a social reformer as well as qualified teacher. She was such a woman whose main purpose was to educate the entire human race. And she set up many schools to meet those purpose. Not only the nation or the country but the whole world is grateful to his for all these social welfare and educational works. The path shown by her is the beginning of women education and another fighter like B R Ambedkar in reducing racial inequality in India.

\section{REFERENCES}

1. Bhattacharyya, J. (2015). Swami Vivekananda's Ideal of Universal Religion. Multidisciplinary Journal of Humanities and Social Sciences. Vol 2, pp 1-8.

2. Gupta, A. K. (2019).Vidyasagar in popular perception: Recovered through anecdotes. SAGE Publication. Vol 6, pp 23-32.

3. Jain, S. (2016). Caste and Education: The Vision of Mahatma Jotirao Phule. BRDU International journal of Multidisciplinary Research. Vol 1, pp 1932 .

4. Katke, S. M. (2019). Savitribai Phule Contribution towards Indian Social Elements - A Study. Journal of Emerging Technologies and Innovative Research (JETIR). Vol 6, pp 25-32.

5. Mangala, K. D. (2018). Savitribai Phule: Revolutionary work and literature. Indian journals.com. Vol 5, pp 71-75.

6. Pandey, R. (2019). Locating Savitribai Phule's Feminism in the Trajectory of Global Feminist Thought. Indian Historical Review. Vol 46(1), pp 86-105.

7. Roy, K. (2010). Rabindranath Tagore Literacy Giant with scientific bent. Science Reporter. Pp 3639.

8. Somkuwar, P. (2014). Dalit Women Poets and New Themes in Poetry. International Journal of English and Literature (IJEL). Vol 4, pp 41-48.

9. Singh, L. N. Life and Times of Mahatma Jyotirao and Krantijyoti Savitribai Phule. pp 1-9.

10. Sircar, J. (2020). Rammohun Roy: His contribution to the making of India. SAGE Publication. Vol 7, pp 53-64.

11. Sirswal, D. R. (2013). Mahatma Jyotiba Phule : A Modern Indian Philosopher. pp 1-12.

12. Varshaa, K. and Vezhaventhan, D. (2018). A study on view of dr.babasaheb ambedkar in formation of modern India .International Journal of Pure and Applied Mathematics. Vol 120, pp 281-296.

13. Wolf, T. (2011). Changing Education: A Note on the "Original and Unusual" Worldvoice, Worldview, and Worldvenue of Jan Comenius and Savitribai Phule. Journal of Applied Christian Leadership. Vol 5, pp 1-27. 